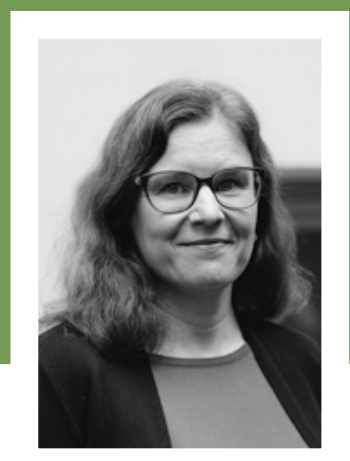

\title{
P̈̈̈̈KIRJOITUS
}

\section{EMME PÄÄSE POLITIIKKAA PAKOON}

$\mathrm{P}$

OlitilkKa on vaikutussuhteita ja vallankäyttöä, kamppailua ja kompromisseja. Politiikka on vuoropuhelua ja neuvotteluja siitä, mitä voidaan tehdä ja millaisiin toimiin päätetään ryhtyä. Keskustelu tiivistyy usein resurssien jakoon ja kysymyksiin siitä, mihin ollaan valmiita käyttämään rahaa.

Politiikka muodostuu ennen kaikkea arvoista, päämääristä ja merkityksistä. Käymme neuvotteluja siitä, mitä asiat tarkoittavat. Sillä on merkitystä, millaista kieltä käytämme ja miten ilmiöitä määrittelemme. Kuka pääsee ääneen ja kenen näkemykset ovat painavimpia?

POLITIIKASSA ON TAPANA tehdä vastakkainasetteluja. Voimme kiistellä asioiden hyvyydestä ja huonoudesta, tai voimme punnita niiden tärkeyttä tai vähempiarvoisuutta. Esimerkit ovat tuttuja niin korkeakoulujen opiskelijavalintauudistusta kuin oppivelvollisuuden pidentämistä koskevista keskusteluista. Aikuiskoulutuskin voidaan asettaa vastakkain muiden koulutusmuotojen kanssa. Koulutuspolitiikassa väitellään esimerkiksi siitä, kannattaako panostaa varhaiskasvatukseen vai yksilön myöhempiin vaiheisiin.

Mitä näissä koulutuspolitiikan keskusteluissa itse asiassa asetetaan vastakkain? On tärkeää, että kaikki saavat parhaan mahdollisen tuen jo lapsuudessa ja nuoruudessa. Olisi kuitenkin kohtuutonta, että vain nuorena saatu koulutus olisi merkityksellistä. Aikuisuudessa näkyvät erot ihmisten hyvinvoinnissa, kyvyissä, asemis- sa ja tulotasossa olisivat näin selitettävissä luonnollisina asioina. Demokraattiseen yhteiskuntaan kuuluu mahdollisuus kouluttautua myös aikuisena ja päästä osalliseksi niistä asioista, joita koulutuksella voi tavoitella.

Koulutus ei kuitenkaan tuota vain hyvä, vaan se on yksi niistä yhteiskunnan mekanismeista, joiden kautta syntyy myös eriarvoisuutta. Koulutuksen prosessit sulkevat toisia sisään ja toisia ulos, ja merkitsevät ihmisiä erilaisin todistuksin, pätevyyksin ja leimoin. Koulutus luo vapauksia mutta myös pakkoja; sen kautta määritetään sitä, millainen on kunnon ihminen ja kansalainen. Koulutus on ristiriitaista: samalla kun yhtäällä edistetään tasa-arvoa, toisaalla luodaan eriarvoisuuksia. Emme ole yksimielisiä siitä, mitkä olisivat parhaita keinoja edistää oikeudenmukaisuutta.

KASVATUSSOSIOLOGIAN TUTKIJAT Becky Francis, Martin Mills ja Ruth Lupton (2017) esittävät, että tutkijoiden tulee olla valmiimpia yhdistämään utopistiset päämäärät käytännön ajatteluun. Meidän tulee rohkeasti koetella tutkimuksemme periaatteita ja löydöksiä koulutuksen tasa-arvoa koskevien ristiriitaisuuksien kautta. Näin tutkijayhteisö voi vaikuttavasti osallistua keskusteluun koulutuksen oikeudenmukaisuudesta. Muuten on vaarana, että tutkimus sivuutetaan päätöksenteossa politiikan kannalta merkityksettömänä.

Vaikka aikuiskasvatus on joutunut ajoittain kamppailemaan omasta asemastaan, se on tällä hetkellä esillä 
päivänpolitiikassa. Sanna Marinin (sd.) hallituksen ohjelmaan kirjattu jatkuvan oppimisen uudistus tähtää työikäisen väestön osaamisen kehittämiseen. Sen suunnitteluun on osallistettu monia toimijatahoja, tutkijoitakin on kuultu seminaareissa ja tapahtumissa. Uudistuksen eteneminen näkyy koulutusorganisaatioissa: korkeakouluissa muodostetaan jatkuvan oppimisen rakenteita ja käytäntöjä, ja oppilaitoksissa mietitään koulutustarjonnan kehittämistä jatkuvan oppimisen tarpeisiin.

Me aikuiskasvatuksen tutkijat voimme ottaa erilaisia positioita suhteessa politiikkaan: Voimme pyrkiä olemaan ulkopuolisia havaintojen tekijöitä. Voimme asettua kritisoimaan politiikkaa ja paljastamaan sen ongelmakohtia. Voimme osallistua politiikantekoon asiantuntijoina tai hankkeissa. Tasa-arvotutkijat Sharon Gewirtz ja Alan Cribb (2020) peräänkuuluttavat tutkimuksen ja politiikan väliseen vuoropuheluun kriittis-demokraattista mallia, jossa politiikka itsessään nähdään mahdollisimman laajasti. Politiikan toimijoita eivät ole vain päätöksentekijät, vaan politiikka tapahtuu jatkuvasti monilla eri tasoilla.

TÄMÄN TEEMANUMERON tekstit tuovat esiin sen moninaisuuden, jolla voimme lähestyä aikuiskoulutuksen politiikkaa. Politiikka läpäisee koulutuksen kaikki ilmiöt ja kerrokset, ja sitä tämä teemanumero ilmentää tiedeartikkeleista puheenvuoroihin. Tekstit keskustelevat keskenään. Ne puhuvat samoista ilmiöistä, mutta katselevat niitä erilaisten teemojen, toimijatahojen ja -tasojen näkökulmista.

Voimme tutkia politiikan tekemistä ja poliittisia prosesseja. Usein tutkimme politiikan seurauksia. Aina kuitenkin tutkimme ilmiöitä niiden poliittisesti tuotetuissa konteksteissaan. Tutkijan kuuluu ymmärtää, että emme pääse politiikkaa pakoon. Toimimme politiikan luomassa kontekstissa ja vaikutamme omalla työllämme siihen, miten ilmiöistä puhutaan ja miten ne ymmärretään. Politiikka tarjoaa meille tutkittavaa, määrittää toimintakenttäämme ja mahdollistaa vaikuttamisen asioihin. Tutkijoina olemme toimijoita paitsi tieteen, myös politiikan kentällä.

\section{Nina Haltia}

teeman päätoimittaja

KT, tutkijatohtori

kasvatustieteiden laitos

Turun yliopisto

\section{LÄHTEET}

Francis, B., Mills, M. \& Lupton, R. (2017). Towards social justice in education: contradictions and dilemmas. Journal of Education Policy 32(4), 414-431. DOI: 10.1080/02680939.2016.1276218

Gewirtz, S. \& Cribb, A. (2020). What works? Academic integrity and the research-policy relationship. British Journal of Sociology of Education 41(6), 794-806. DOI: 10.1080/01425692.2020.1755226 